\title{
The Effects of Privatization on Efficiency: How Does Privatization Work?
}

\author{
CAGLA OKTEN \\ Bilkent University, Ankara, Turkey
}

and

\author{
K. PEREN ARIN * \\ Massey University, Auckland, New Zealand \\ Centre of Applied Macroeconomic Analysis (CAMA), Canberra, Australia
}

\begin{abstract}
Summary. - Uncovering the effects of privatization is difficult, because privatization of a particular firm usually is not an accident. This paper tests the effects of privatization on productive and allocative (market) efficiency using a rich panel data set of 22 privatized cement plants from Turkey in the 1983-99 period. Since all public cement firms were privatized and we have preand post-privatization data for all, we are able to avoid the problem of endogeneity associated with sample selection. Our analysis goes beyond just examining the privatization effects and explores how privatization really works. Changes in objectives of the firm (ownership effect) and changes in market structure (environment effect) may both be responsible for privatization outcomes. We find that ownership effects are sufficient to achieve improvements in labor productivity. Our results on allocative efficiency, however, are dependent on changes in the competitive environment. While all plants seem to improve labor productivity through work force reductions, plants privatized to foreign buyers also increase their capital and investment significantly.

(c) 2006 Elsevier Ltd. All rights reserved.
\end{abstract}

Key words - SOEs, privatization, efficiency, Middle East, Turkey

\section{INTRODUCTION}

In the last two decades, many countries have launched extensive privatization programs. There is now a growing body of literature on the effects of privatization on productive efficiency. We contribute to this literature in three ways. First, we present a complete picture of privatization as we analyze the effects of privatization on both productive and allocative (market) efficiency using data from the Turkish cement industry. Second, our analysis goes beyond examining the privatization effects and explores how privatization really works. Is it the changing objectives due to private ownership or a change in the competitive environment that causes possible efficiency gains? By focusing on this question, we aim to provide insights to researchers and policymakers in their analy- sis/design of other privatization experiments. Third, our data set enables us to avoid the endogeneity problem associated with sample selection. All public cement plants in Turkey have been privatized and we have pre- and post-privatization data for all.

Privatization efforts in Turkey, fueled by the forces of globalization, started in 1985. The given motivations for privatization were to relieve the state of the burdens of inefficient

\footnotetext{
* The authors would like to thank Ayca Altintig, Henk Berkman, Eberhard Feess, Kevin Hasker, Ben Jacobsen, Simon Johnson, Sudipta Sarangi, Christopher Udry, the participants at the 2002 AEA session on privatization and the three anonymous referees for their valuable comments and suggestions. Final revision accepted: January 10, 2006.
} 
state industries, improve efficiency and create revenue for the government. Although the privatization process in Turkey has started earlier than in most developing countries, its progress - measured in terms of the size of divestiture-has been slower compared with the principal Latin American and Eastern European cases (Ercan \& Onis, 2001). Since its start in 1985, the total proceeds from privatization efforts have amounted to $\$ 9.4$ billion by 2005 .

Turkey is an important country in the cement sector. It is the largest exporter and third largest producer of cement in Europe and second largest exporter and 12th largest producer of cement in the world (OAIB, Cimento Sektoru Raporu, 2003). ${ }^{1}$ The industry can be considered an oligopoly since ownership is concentrated and due to high transportation costs each plant has some monopoly power in its hinterland. According to Shirley and Walsh (2001), both the theoretical literature and the empirical literature are not conclusive about the merits of private ownership in monopolistic markets.

The economic theory of privatization is a subset of the vast body of literature concerning the economics of ownership and the role for government ownership of productive resources. There are two main branches in this literature: The Social View (Shapiro \& Willig, 1990) and the Agency View (Shleifer \& Vishny, 1994; Vickers \& Yarrow, 1988). In this paper, we identify the predictions of the existing models of ownership and empirically test the validity of these predictions.

Our results show that privatization increases labor productivity and decreases prices significantly, indicating an improvement in both productive and allocative efficiency. Our results on productive efficiency are robust to controlling for changes in the competitive environment (market structure), while privatization no longer has a significant effect on prices in the presence of this control. We find evidence that technology becomes more capital intensive for plants privatized to foreign firms as all the three, capital endowment, investment and capital labor ratios, increase for these plants while plants purchased by domestic firms do not experience a significant increase in their investment and capital levels.

These results are not biased due to sample selection problems, since all public cement plants in Turkey were privatized and we have pre- and post-privatization data for all. Due to data limitations, the empirical literature on privatization typically presents studies of partial privatization experiments in which some of the firms in the analysis are privatized while others remain public. Hence, it is arguable that firms selected for privatization might have unobserved characteristics that could have affected results.

Most existing empirical studies on privatization either compare private and public firms at the same point in time or are gathered from studies of privatization of the before-after variety examining the averages of key variables before and after privatization and testing for significant changes. Cross-sectional studies may have difficulty in controlling for firm-specific effects, while before-after studies may fail to control for period-specific effects. We contribute to this literature by fully controlling for firm and time specific effects using a fixed effect panel data estimator.

In Section 2, we review the theoretical and the empirical literature on privatization. Section 3 describes the privatization environment and the cement industry in Turkey. Section 4 describes our data. Section 5 presents the econometric framework. Section 6 presents and discusses the results and Section 7 concludes.

\section{LITERATURE REVIEW}

\section{(a) Theoretical literature on privatization}

The economic theory of privatization is a subset of the vast body of literature examining the economics of ownership and the role of government ownership of productive resources. There are two main branches in this literature: The Social View and the Agency View.

According to the Social View (Shapiro \& Willig, 1990), state owned enterprises (SOEs) are capable of curing market failures by implementing pricing policies that take account of social marginal costs and benefits of production. A privately owned firm is expected to maximize profits, whereas a state owned firm is expected to maximize social welfare. For example, in a natural monopoly market structure, efficiency calls for a single firm to exist. A profit maximizing monopoly will, however, charge too high a price and produce too low a quantity. This potential inefficiency can be solved by state ownership.

The Agency View of firm ownership presents a strong critique of this theory. There are two 
complementary strands of the literature which differ as to whether the agency conflict is with the manager or the politician. Vickers and Yarrow (1988) argue that managers of SOEs may lack high-powered incentives or proper monitoring. Shleifer and Vishny (1994) stress that political interference in the firm results in excessive employment, poor choices of product and location, lack of investments and ill-defined incentives for managers.

The Social View unequivocally predicts that efficient technology will be chosen by state owned firms. Models of Agency View, on the other hand, while predicting that inefficient technologies will be chosen by politicians/managers, have different predictions for the direction of the distortion in the production process. They either predict that state owned firms will have low investment levels (Shleifer \& Vishny, 1994), or that they will use excess capital as well as excess labor (Vickers \& Yarrow, 1988). The over-capitalization argument stems from bureaucratic inefficiency models. The founder of this line of literature, Niskanen (1975), proposed that bureaucrats are inclined to maximize their total budget rather than the utility of their sponsors. Vickers and Yarrow (1988) argue that the bureaucrats will subject the state owned firm to over-investment and over-capitalization to justify high salaries and perks.

On allocative efficiency, the Social View predicts that prices are likely to rise as a result of privatization. The Agency View, on the other hand, predicts that if a reasonable degree of competition ensues, then allocative efficiency may actually increase as firms increase their productivity after privatization. In this paper, we test the models of the Social View and of the Agency View by empirically examining whether privatization improves allocative efficiency and firm productivity. We further differentiate between the two models of the Agency View by examining how privatization affects a firm's capital endowment.

\section{(b) Empirical literature on privatization}

\section{(i) Privatization and productive efficiency}

Firm performance has been the focus of the empirical literature on privatization. Studies cited in a survey of empirical studies of privatization almost unanimously report increases in firm performance associated with privatization (Megginson \& Netter, 2001). ${ }^{2}$ In another review of the literature, Shirley and Walsh (2001) find greater ambiguity about privatiza- tion in theoretical literature than in the empirical literature and they conclude that empirical literature strongly favors privatization in competitive markets. However, ambiguity of the theoretical literature about ownership in less competitive markets seems better justified since the empirical literature is also less conclusive on the effects of ownership in such markets. Most of these studies surveyed in review articles compare post-privatization performance changes with either a comparison group of non-privatized firms or compare three year mean/ median performance of privatized firms to their own mean/median performance during their last three years as state owned firms.

Critics of these findings are quick to point out that all of the gains researchers have documented after privatization are due to selection bias. The argument is that better firms are privatized first and their comparison to more poorly performing firms that happen to remain public gives a spurious relationship between privatization and firm performance. Cross-sectional studies may not be able to satisfactorily control for firm-specific effects and therefore address the selection problem for privatization. While comparing before and after three year averages of performance measures might be less biased, even that method may not entirely solve the selection problem. One could argue that those firms would have improved at any rate even if they were not privatized or other reforms that accompany the privatization process may have been responsible for the changes observed (Omran, 2004). When Omran compares before and after privatization averages of performance measures of privatized firms from Egypt, he finds a significant increase in performance. But when he carries out the same exercise for firms that remain state owned, he finds that they also improve after the privatization period though they themselves are not privatized. Either the improvement of privatized firms has spillover effects on state-owned firms or privatization has nothing to do with the changes observed. The author suggests that other economic reforms that enhanced the competitive environment in which his sample of privatized and state-owned firms was operating might have been responsible for his findings.

Some recent studies control for unobserved firm heterogeneity using firm fixed effects in a panel data analysis (Earle \& Telegdy, 2002; Ehrlich, Gallais-Hamonno, Liu, \& Lutter, 1994; Frydman, Gray, Hessel, \& Rapaczynski, 1999; Villalonga, 2000; Wallsten, 2001). The 
results of these studies on privatization and firm performance are mixed. Ehrlich et al. (1994) use a sample of 23 comparable international airlines of different ownership categories over the period 1973-83. Their results suggest that private ownership leads to higher rates of productivity growth and declining costs in the long run, and that these differences are not affected by the regulatory environment. Their estimates suggest that the short-run effects of changes from state to private ownership on productivity and costs are ambiguous.

Villalonga (2000) examines 24 Spanish firms from different industries and finds that privatization does not increase firm efficiency (defined as rate of return on assets). She argues that political factors such as the business cycle during which the firm is privatized and foreign ownership are important determinants of firm efficiency. Wallsten (2001) finds that in the telecommunications sector, privatization by itself does not appear to generate many benefits and is negatively correlated with main line penetration. He points out the importance of regulatory framework ensuing from privatization as he finds that privatization combined with the existence of a separate regulator is correlated with increased connection capacity and labor efficiency as measured by employees per main line.

Earle and Telegdy (2002) find that privatization increases labor productivity growth in their heterogeneous sample of Romanian firms. Frydman et al. (1999) find that privatization to outsider owners including foreigners has significant effects on revenue performance, but not on cost reduction using data from the Czech Republic, Hungary and Poland, of 218 state owned firms, of which 128 were privatized during the period from 1990 to 1994.

We contribute to the literature on the effects of privatization on firm performance in three important ways: (1) we control for firm and time fixed effects in our baseline regressions, (2) our sample allows us to control for endogeneity which has been a problem for previous research, and (3) we assess the effects of ownership on firm performance in an oligopolistic market. According to a review article by Shirley and Walsh (2001), the empirical literature is not conclusive on the effects of ownership in less competitive markets.

\section{(ii) Privatization and allocative efficiency}

Studies that examine the effect of privatization on allocative efficiency are rare (Meggin- son \& Netter, 2001). These studies typically find that prices either increase or do not change after privatization. La Porta and Lopez-de-Silanes (1999) analyze Mexican firms from a variety of industries and find that consumer prices increase after privatization. In their analysis of the water and sewerage industry of England and Wales, Saal and Parker (2001) find that output prices increase, and furthermore, total price performance indices reveal that increases in output prices have outstripped increases in input costs. On the other hand, in a cross-country panel study of the telecommunications sector, Wallsten (2001) finds that prices are not correlated with privatization but are negatively correlated with competition; measured by the number of mobile operators not owned by the incumbent.

It is unrealistic to expect that the effects of privatization on prices will be the same in every industry. Market structure of an industry (market power of firms in the industry) as well as firms' productivity will affect consumer prices. In our study, we contribute to this literature by striving to differentiate the effects of private ownership from the changes in market structure and competitive environment induced by privatization and other economic reforms.

\section{(iii) Privatization and input choice}

Empirical studies of privatization do not directly examine the changes in input choice resulting from privatization. Rather, they report changes in employment and capital investment, which may suggest a change in technology. In their survey article, Megginson and Netter (2001) report that almost all of the 22 studies from non-transition economies that they review find that capital investment spending increases significantly as firms are privatized. Perhaps surprisingly, they report that these studies are far less unanimous regarding the impact of privatization on employment levels in privatized firms.

La Porta and Lopez-de-Silanes (1999), in their study of 233 privatized Mexican firms, find that the ratios of investment to sales and investment to fixed assets significantly increase after privatization while employment significantly decreases.

Bhaskar and Khan (1995) find that privatization has a large and significant negative effect on white-collar workers using employment data from Bangladesh, for 62 jute mills of which 31 were privatized. 
In this study, we contribute to this literature by analyzing how capital, investment and employment and capital labor ratios change for privatized firms in the Turkish cement industry.

\section{(iv) Privatization and market structure}

Few studies have sought to estimate the effects of market structure along with privatization. These studies typically include some type of measure for market concentration as an additional control when they measure the effects of privatization on firm productivity. In general, they do not analyze how privatization affects market structure or how changes in market structure affect allocative efficiency. Angelucci, Estrin, Konings, and Zolkiewski (2001) analyze the effects of competitive pressures (measured by Herfindahl index (HHI) and share of imports in sales) and ownership changes on productivity in Bulgaria, Poland, and Romania. Anderson, Lee, and Murrell (2000) analyze the effects of competition and ownership on the productivity of the newly privatized enterprises using data from Mongolia. Kattuman and Domanski (1997) analyze market concentration as a result of mass privatization in Poland and find that concentration rapidly increases in several markets. Warzynski (2003) in his study of 300 Ukrainian firms finds that competition does not have a significant effect on firm performance measured by productivity and profitability, while privatization has a marginal positive significant effect on profitability and an insignificant effect on productivity. He points out, however, that competition and privatization might be complementary measures, as he finds that competition increases the performance of privatized firms.

Kikeri and Nellis (2004) point out that the mounting empirical evidence of privatization's benefits coincides with increasing dissatisfaction and opposition among citizens and policymakers and they suggest strengthening the effects of privatization by deepening efforts to promote competition and regulatory frameworks.

We contribute to the literature by analyzing how privatization affects market concentration in an oligopolistic industry and by controlling for market concentration in our analysis of privatization effects on allocative efficiency as well as firm productivity.

\section{(v) Privatization and corporate governance}

There is an emerging literature on the importance of corporate governance in privatization experiments. By empirically testing the theoretical predictions of Shleifer and Vishny (1997) and Boubakri et al. (2005) find that ownership concentration is significantly and positively related to post-privatization performance. Their results suggest that large shareholders, whose wealth depends on firm performance, have more incentives to monitor management, and ensure that their resources are not diverted.

Recent papers (Dharwadkar, 2000; Ramamurti, 2000) have examined the situation in emerging economies where neither capital markets nor economic institutions are well developed, emphasizing the importance of government's residual ownership and the type of capital the firm attracts to understand the results of privatization cases. Studies by Frydman et al. (1999) and Villalonga (2000) point out to foreign ownership as an important determinant of firm efficiency for the privatized firms.

In our study, we have data on the identity of buyers which allows us to differentiate the effects of foreign versus domestic ownership on privatization outcomes. Unfortunately, our sample does not allow us to examine the effects of ownership concentration on firm performance. Cement plants were privatized in total via blocksales with the exception of two plants which were partially sold in public offerings. This is not a sufficient variation to explore the effects of ownership concentration on firm performance as well as the relative merits of the two methods. ${ }^{3}$

\section{INSTITUTIONAL BACKGROUND}

\section{(a) Privatization in Turkey}

Historically, Turkey has a long experience of relying heavily on SOEs. SOEs were established during the 1930 s by the government to jumpstart the economy that had collapsed with the end of the Ottoman era in 1923. Over the years SOEs grew enormously, leaving the control of a large section of the economy to bureaucrats and politicians. Politicians exploited SOEs to provide jobs to their constituents at the expense of consumers, who were faced with higher prices. Consequently, in the 1980s, SOEs began to be perceived negatively due to poor financial performance, overstaffing, dependence on subsidies, protected markets and corruption (Ertuna, 1998).

After a Military Regime (1980-83), the first party that came to power was the Motherland 
Party (ANAP) under the leadership of Prime Minister Turgut Ozal. Ozal was a strong supporter of Thatcherism that promoted a reduction of the state's role in the economy. Privatization first entered the political agenda with Ozal's trade and capital account liberalization program in 1984.

Despite this initial enthusiasm, the privatization process has been slow. From its start in 1985 up to 2005 , the total proceeds from privatization efforts have amounted to $\$ 9.4$ billion. More than half of this was realized in the 2000 04 period after the 1999 IMF Stand By agreement, which placed a particular emphasis on privatization. Block sales have been the most prevalent method of privatization.

The privatization reforms have not been fully carried out as intended, due to the lack of a legal framework, conflicting laws and a wavering political will. Privatization efforts faced strong opposition by entrenched vested interests, notably senior bureaucrats in government departments and SOEs, Workers' Unions who have expressed serious concern about the possibility of mass lay offs and leftist political parties (Karatas, 2001). Still, numerous companies have been privatized. The share of the public sector in total value added manufacturing is down from $40 \%$ in 1986 to $18.5 \%$ in 2000 , which is a $54 \%$ reduction.

\section{(b) Privatization process in the cement industry}

Cement is an extremely capital intensive industry making entry into this sector difficult. Furthermore, high transportation costs via land generally limit transportation of cement to an area within two to three hundred kilometers of any plant site. As a result, cement industry in Turkey today is an oligopoly with about eleven companies owning a total of 39 plants and each plant is a local monopoly within its surrounding area due to high transportation costs. ${ }^{4}$

The first cement plant of Turkey was established in 1911 by a private firm. By 1950, four more private plants had been built. Only after 1950 did the cement industry develop on a large scale by means of a government initiative. A public enterprise, CISAN (Turkish acronym for Turkish Cement Industry Co. later named CITOSAN), was established in 1953 to build 15 plants in various regions. Before the privatization of the cement plants began in 1989, the public share in the cement industry was nearly $40 \%$ (Saygili \& Taymaz, 2001). It is believed that each plant was able to exercise some monopoly power within its hinterland (Ertuna, 1998), most probably due to the distance between plants and the lack of proper transportation facilities in the public sector.

In 1986 a French company, Sema-Metra Conceil, was contracted by the Turkish government and the World Bank to prepare two reports, one on the structural regulation of the cement sector and privatization and the other on the plan for the reorganization of CITOSAN. In the latter report, Sema-Metra Conceil suggested that plants in the west be privatized first since they could be as profitable as private plants, and recommended that the eastern plants be restructured prior to privatization. The report also suggested privatization on a plant-by-plant basis, as the sale of the state firm as a single entity may have led to an unhealthy monopoly (Tallant, 1993). In 1986, there was a major change in the economic environment of the cement plants. Prior to 1986, the Turkish Cement Producers Association (TCPA) set prices and market areas for all cement companies, however, after 1986 firms were encouraged to operate independently and maximize profits. Sema-Metra's first report might have partially led to this change.

Privatization in the cement industry started in 1989, with the initial sale of five factories to the French firm Cement Francais (SCF). By 1998, the sale of 22 cement plants had been completed. ${ }^{5}$ Revenues from the sale of cement plants amounted to about $20 \%(10 \%)$ of total privatization revenues as of 1998 (2005). The recommendations of the Sema-Metra report were taken into consideration, and the western plants were privatized first. ${ }^{6}$ It may also be the case that the privatization of the eastern plants was delayed, as the eastern region suffered from unemployment and terrorism throughout the 1990s and the public enterprises were used as means of employment.

Privatization of the cement plants was carried out under the Privatization Administration of Turkey. Most of the privatizations were realized through block sales using closed-bid auctions and through a combination of block sales and public offerings in a few cases. Table 1 presents all plants that were privatized, with their establishment and privatization dates and the names of their buyers.

Saygili and Taymaz (2001) pointed out that holding companies had a tendency to acquire plants in specific regions. For instance, Rumeli Holding bought plants in the eastern region 
Table 1. The privatized cement factories in Turkey

\begin{tabular}{|c|c|c|c|}
\hline Company & $\begin{array}{c}\text { Established } \\
\text { in }\end{array}$ & $\begin{array}{l}\text { Privatized } \\
\text { in }\end{array}$ & Buyer \\
\hline Afyon & 1955 & 1989 & $\begin{array}{l}\text { Ciment } \\
\text { Francais }\end{array}$ \\
\hline Ankara & 1926 & 1989 & $\begin{array}{l}\text { Ciment } \\
\text { Francais }\end{array}$ \\
\hline Balikesir & 1958 & 1989 & $\begin{array}{l}\text { Ciment } \\
\text { Francais }\end{array}$ \\
\hline Pinarhisar & 1958 & 1989 & $\begin{array}{l}\text { Ciment } \\
\text { Francais }\end{array}$ \\
\hline Soke & 1955 & 1989 & $\begin{array}{l}\text { Ciment } \\
\text { Francais }\end{array}$ \\
\hline Corum & 1959 & 1992 & Yibitas \\
\hline Denizli & 1987 & 1992 & Modern \\
\hline Gaziantep & 1957 & 1992 & Rumeli \\
\hline Nigde & 1957 & 1992 & $\begin{array}{c}\text { OYAK- } \\
\text { SABANCI }\end{array}$ \\
\hline Sivas & 1943 & 1992 & Yibitas \\
\hline Trabzon & 1966 & 1992 & Rumeli \\
\hline Askale & 1968 & 1993 & Ercimsan \\
\hline Bartin & 1962 & 1993 & Rumeli \\
\hline Ladik & 1983 & 1993 & Rumeli \\
\hline Sanliurfa & 1986 & 1993 & Rumeli \\
\hline Adiyaman & 1983 & 1995 & Teksko \\
\hline Elazig & 1954 & 1996 & OYAK-GAMA \\
\hline Lalapasa & 1991 & 1996 & Rumeli \\
\hline Kars & 1969 & 1996 & Cimentas \\
\hline Van & 1966 & 1996 & Rumeli \\
\hline Ergani & 1984 & 1997 & Rumeli \\
\hline Kurtalan & 1976 & 1998 & $\begin{array}{l}\text { Canlar } \\
\text { Otomotiv }\end{array}$ \\
\hline
\end{tabular}

and along the Black Sea coast. The Turkish Armed Forces Pension Fund (OYAK) and Sabanci Holding, one of the biggest holding companies in Turkey, formed an alliance and purchased companies in Central Anatolia, Southern Anatolia and Marmara regions. Set Cement Holding (a subsidiary of Italcementi which merged with Ciment Francais) focused on Central and Western regions, and finally, Lafarge and Yibitas own cement plants in neighboring provinces of Central Anatolia. Saygili and Taymaz (2001) argued that privatization through block sales, instead of public offerings in the stock market, gave rise to bigger regional monopolies. According to the report of the Central Anatolian Board of Export, however, the privatization of public cement plants increased competition in the industry and decreased prices.

In order to gather some anecdotal evidence, we asked the managers of the privatized cement plants their views on the effects of privatization in their sector. Six managers out of 22 were willing to share their views under the condition of strict anonymity. They all indicated that their plants increased productivity drastically as a result of privatization. Five out of the six managers rated the introduction of new production methods and automation as the most important factor in this improvement. One manager rated the changed incentives of employees as the most important factor, while he rated automation as a very important determinant of increased productivity. They all indicated that their capacity and output have increased as a result of privatization and that profit margins have been falling due to fierce competition and the recent decline in aggregate demand due to the economic crisis in 2002.

Today, the Turkish cement industry consists of 39 private plants, some owned by giant industrial holdings and others by small oneplant companies. There are four foreign investors in the industry, namely, French Lafarge Coppee, Ciment Vicat, German Heidelberger Zement/CBR, and Italian Italcementi. Cement consumption continues to grow at sound levels and Turkey continues to be a major exporter of cement. Turkey is the largest exporter and third largest producer of cement in Europe and second largest exporter and 12th largest producer of cement in the world (OAIB, Cimento Sektoru Raporu, 2003).

\section{DATA}

All of the Turkish publicly owned cement plants were privatized during 1989-98. Since our sample includes all of these plants with their pre- and post-privatization data, we are able to look at a more complete picture of privatization and avoid the problem of endogeneity associated with sample selection. The privatization of the public cement plants in Turkey is like a natural experiment that allows us to examine the effects of privatization in an almost ideal setting.

Our data spans a period from 1983 to 1999 for many of the variables of interest, though the time series is shorter for some variables and the panel is not always balanced. Our data on output, employment and investment are constructed from the official statistics of the Privatization Administration of Turkey. Our data on capital and sales are constructed from the Istanbul Chamber of Industry's surveys (ISO500) conducted on the 500 largest firms 
Table 2. Description of variables

\begin{tabular}{|c|c|}
\hline Variable & Description \\
\hline Capacity & The minimum efficient scale of the firm, measured in tons scaled by 1,000 \\
\hline Capital & $\begin{array}{l}\text { Assets measured in Turkish Liras, deflated by the wholesale price index of } \\
\text { Central Bank of Turkey, } 1987=100 \text { and scaled by } 1,000,000\end{array}$ \\
\hline Capital/labor ratio & Capital divided by number of workers \\
\hline Herfindahl in & $\begin{array}{l}\text { A measure of market concentration, which is calculated by summing the squares of } \\
\text { firms' market shares }\end{array}$ \\
\hline Investment & $\begin{array}{l}\text { The investment expenditures of the firm, measured in Turkish Liras, deflated by the } \\
\text { wholesale price index and scaled by } 1,000,000\end{array}$ \\
\hline Labor & The number of workers employed by the firm \\
\hline Labor productivity & Per capita cement production, measured in tons \\
\hline Output & Output sold by the firm, measured in tons scaled b \\
\hline Prices & The sale price per ton, deflated by wholesale price index and scaled by $1,000,000$ \\
\hline Relative inflation rate & Firm price inflation rate minus wholesale price inflation rate \\
\hline Sales & Sales measured in Turkish Liras, deflated by the price index and scaled by $1,000,000$ \\
\hline
\end{tabular}

of Turkey. We also have sales and employment data on privately owned plants from ISO500 that we use in a robustness check. Table 2 describes the variables used in our analysis.

There are a few other empirical studies that analyze the impact of privatization on the Turkish cement industry (Ozmucur, 1998; Saygili \& Taymaz, 2001; Tallant, 1993). These studies focus on the effects of privatization on firm productivity and do not analyze how privatization affects allocative efficiency, market structure and input choice. Also, their analysis does not extend beyond 1995 and hence at least six plants are treated as public during the study period.

Interestingly, their results on firm productivity are mixed. Ozmucur (1998) analyzes a panel of public and private cement establishments, using the results of the Istanbul Chamber of Industry's surveys on the 500 largest firms of Turkey. He estimates a separate equation for each firm to determine the year of structural change for employment and labor productivity for the 1981-95 period. He finds that structural change coincided with time of privatization for public firms and reduction in employment, which to a degree happened in all firms, was significantly higher in the privatized firms.

Tallant (1993) analyzes the relative efficiency of public sector with respect to the private sector in Turkish cement industry in a crosssectional study. He finds that private plants are more efficient in terms of productivity and capacity utilization. However, he argues that the better showing in physical measures is closely related to geographic location as western plants perform better, which indicates that the initial location decision has had more to do with firm performance than public ownership per se.

Saygili and Taymaz (2001) analyze the effects of ownership and privatization on technical efficiency using a panel data set of public and private cement plants for the years 1980-95 and measure the relative performance of private or privatized firms with respect to the six plants that remain public during the study period. In fact since they lack post-privatization data for two other plants (Adiyaman and Askale), they have eight plants in their comparison group. They find that private plants were clearly more efficient than the comparison group, but the average technical efficiency of private plants and public plants privatized in 1989 revealed no statistically significant difference.

How can we reconcile the differences in results as to the effects of privatization on firm efficiency? One explanation can be the differences in the competitive environments of these plants. Perhaps plants privatized in 1989 performed as well as private plants due to a more competitive environment in the western regions where they coexisted with private plants. In our empirical analysis, we will control for the market structure and hence the competitive environment when we measure the effects of privatization. Another explanation is perhaps in the differences in the questions asked. The studies of Tallant, Saygili, and Taymaz ask how private plants compare with public ones. Whereas Ozmucur and our study focus on how privatization affects performance. Since we have post-privatization data for plants priv- 
atized in the 1995-98 period, we can test the effects of privatization on eastern plants which were privatized later as well as western plants which were privatized earlier.

\section{ECONOMETRIC FRAMEWORK}

We evaluate the impact of privatization on firm performance by adopting the following framework:

$y_{i t}=\alpha P_{i t}+\beta X_{i t}+\mu_{i}+\delta_{t} D_{t}+\varepsilon_{i t}$,

where $i$ denotes plant $i$ and $t$ denotes year $t, y_{i t}$ is the outcome variable of interest such as labor productivity price, and $P_{i t}$ is the treatment variable (privatization effect) that is equal to 1 if year $t$ is a post-privatization period for firm $i$ and 0 otherwise, and $X_{i t}$ is a vector of additional regressors that we use in some specifications.

One important regressor in $X_{i t}$ is the HHI of the region in which the plant is located. The HHI is obtained by summing the squares of the regional market shares of cement companies. We use HHI to measure the effects of privatization that operate through the changes in the firm's competitive environment. This specification allows us to differentiate between the effects of private ownership and the effects of changes in market structure due to privatization reforms. $\mu_{i}$ is the plant fixed effect and $D_{t}$ is a dummy which is equal to 1 in year $t$ and is 0 otherwise. Coefficient $\alpha$ will capture the effect of privatization on our outcome variable. The above equation denotes our standard baseline regression.

\section{RESULTS AND DISCUSSION}

Table 3 presents the comparison of the three year averages of the variables of interest before and after privatization. Our results indicate that labor productivity, investment and capital are significantly higher, whereas prices and employment are significantly lower in the post-privatization period. Although labor productivity is significantly higher in the postprivatization period, it is still less than average productivity in the cement sector in the world outside of China which was about 3,600 tons per employee in the year 2000 according to a report by Klee (2003).

In the rest of the paper, we analyze the effects of privatization on productive and allocative efficiency using panel data methods and hence make full use of the richness of our data set. Our objectives are to (1) check whether the results listed in Table 3 withstand a rigorous econometric treatment where we use panel data methods with firm-specific and period-specific fixed effects, (2) examine potential factors such as ownership type (foreign versus domestic), work force reductions, choice of capital intensity and investment and changes in competitive

Table 3. Comparison of means three years before and after privatization ${ }^{\mathrm{a}}$

\begin{tabular}{lcccc}
\hline Variable & Number of obs. & Before privatization mean & After privatization mean & $t$-Statistics \\
\hline Labor productivity & 22 & $1,167.212$ & $2,132.207$ & $6.08^{* * *}$ \\
& & $(84.99)$ & $(166.58)$ & $-2.31^{* *}$ \\
Price & 21 & 0.036 & 0.033 & \\
& & $(0.002)$ & $(0.001)$ & $-8.40^{* * *}$ \\
Labor & 22 & 314.83 & 204.31 & $(10.98)$ \\
& & $(12.47)$ & $16,978.18$ & $2.73^{* * *}$ \\
Capital & 15 & $10,026.51$ & $(3356.05)$ & $3.98^{* * *}$ \\
& & $(1743.58)$ & 88.21 & $(18.18)$ \\
Capital labor ratio & 15 & 30.60 & $2,158.24$ & $2.60^{* * *}$ \\
& & $(5.96)$ & $(510.06)$ & \\
Investment & 22 & $(225.68$ &
\end{tabular}

a Data from the three years before and after the year of privatization are included in the before privatization and after privatization data sets, respectively. If data were missing for one or two of these years for a given firm in the pre(post-) privatization period, then we also excluded the symmetric year in the post- (pre-) privatization period to ensure that the comparison is symmetric.

Significant at $10 \%$.

** Significant at $5 \%$.

*** Significant at $1 \%$. 
environment that may have contributed to improvements in efficiency.

\section{(a) Privatization and productive efficiency}

Regressions 1-4, presented in Table 4, show the effects of privatization on labor productivity (in logs). We have controlled for firm-specific and period-specific effects by adopting a firm fixed effect specification and including year dummies. We observe that privatization has a positive and significant effect on labor productivity in Regression 1. A switch from public ownership to private ownership increases labor productivity by $24 \%{ }^{7}$ In Regression 2 , we break down the effect of privatization according to the type of buyer and have two different dummy variables: domestic and foreign. Domestic (foreign) is equal to 1 in the postprivatization period if the plant is purchased by a domestic (foreign) buyer. Both variables have positive and significant effect on labor productivity. This result contrasts with the studies conducted by Frydman et al. (1999) and Villalonga (2000) that point out foreign ownership as an important determinant of firm efficiency for the privatized firms.

In Regression 3, we also control for log of the capital labor ratio in addition to the controls used in Regression 1. We can interpret Regression 3 as a Cobb-Douglas production function specification. ${ }^{8}$ The privatization effect remains positive and significant though the increase in labor productivity drops from $24 \%$ to $21 \%$ when we control for the capital labor ratio. The capital labor ratio, as expected, has a positive and significant effect on labor productivity though its coefficient is smaller than expected. Regression 4 replicates Regression 2 including capital labor ratio as an explanatory variable. Once again both domestic and foreign types of ownerships are found to have positive and significant effect on labor productivity of privatized plants. Hence, we conclude that privatization has a positive and significant effect on productive efficiency.

\section{(b) Privatization and allocative efficiency}

In Table 4, Regressions 5 and 6 present the effects of privatization on allocative efficiency. Our measures for allocative efficiency are plant specific cement prices (in $\log$ ) and the relative inflation rate. The relative inflation rate is calculated by subtracting the wholesale price index inflation rate from the plant price inflation rate. We know that prior to the price deregulation in 1986, the price of each publicly owned plant

Table 4. Privatization and efficiency method: fixed effects estimation (firm level)

\begin{tabular}{|c|c|c|c|c|c|c|}
\hline \multirow[t]{2}{*}{ Dependent variable } & \multicolumn{4}{|c|}{ Productive efficiency } & \multicolumn{2}{|c|}{ Allocative efficiency } \\
\hline & $\begin{array}{c}\text { Labor } \\
\text { productivity } \\
(\log ) \\
(1)\end{array}$ & $\begin{array}{c}\text { Labor } \\
\text { productivity } \\
(\log ) \\
(2)\end{array}$ & $\begin{array}{c}\text { Labor } \\
\text { productivity } \\
\text { (log) } C-D \\
\text { (3) }\end{array}$ & $\begin{array}{c}\text { Labor } \\
\text { productivity } \\
\text { (log) } C-D \\
\text { (4) }\end{array}$ & $\begin{array}{c}\text { Price } \\
(\log ) \\
(5)\end{array}$ & $\begin{array}{c}\text { Relative } \\
\text { inflation } \\
\text { rate } \\
(6)\end{array}$ \\
\hline Privatization effect & $\begin{array}{l}0.215^{* * *} \\
(5.00)\end{array}$ & & $\begin{array}{l}0.188^{* * *} \\
(3.47)\end{array}$ & & $\begin{array}{l}-0.392^{*} \\
(-1.79)\end{array}$ & $\begin{array}{l}-0.085^{*} \\
(-1.91)\end{array}$ \\
\hline Domestic & & $\begin{array}{l}0.206^{* * *} \\
(4.74)\end{array}$ & & $\begin{array}{l}0.196^{* * *} \\
(3.44)\end{array}$ & & \\
\hline Foreign & & $\begin{array}{l}0.282^{* * * *} \\
(3.88)\end{array}$ & & $\begin{array}{l}0.165^{* *} \\
(2.22)\end{array}$ & & \\
\hline Capital labor ratio (log) & & & $\begin{array}{l}0.135^{* * *} \\
(3.89)\end{array}$ & $\begin{array}{l}0.139^{* * *} \\
(3.88)\end{array}$ & & \\
\hline Year dummies & Yes & Yes & Yes & Yes & Yes & Yes \\
\hline$F$-statistic & 103.94 & $F=98.05$ & $F=69.77$ & $F=65.50$ & 46.71 & 41.76 \\
\hline Overall $R^{2}$ & 0.563 & 0.581 & 0.760 & 0.761 & 0.696 & 0.706 \\
\hline $\begin{array}{l}\text { Test statistic for plant } \\
\text { effects ( } p \text {-value) }\end{array}$ & $\begin{array}{c}F=30.71 \\
(0.00)\end{array}$ & $\begin{array}{c}F=29.17 \\
(0.00)\end{array}$ & $\begin{array}{c}F=10.26 \\
(0.00)\end{array}$ & $\begin{array}{c}F=10.18 \\
(0.00)\end{array}$ & $\begin{array}{c}F=5.27 \\
(0.00)\end{array}$ & $\begin{array}{c}F=0.56 \\
(0.94)\end{array}$ \\
\hline Number of observations & 266 & 266 & 165 & 165 & 194 & 329 \\
\hline
\end{tabular}

$t$-Statistics are in parentheses.

* Significant at $10 \%$.

** Significant at $5 \%$.

*** Significant at $1 \%$. 
was set to the same amount by CITOSAN, a public enterprise. Unfortunately, we do not have data on these prices but we have an industry-wide price index from the State Planning Institute of Turkey. Hence, we calculate the plant price inflation rate by using this industry-wide price index prior to 1986 , and by using plant specific prices post-1986. Since this variable merely indicates rate of change, it is possible to construct it using two different price indices as long as we code the year for which we switch from one index to the next as missing. Our goal in constructing the relative inflation rate is to achieve a longer series on price.

Both regressions control for plant specific and period specific effects by adopting a firm fixed effect specification and including year dummies. We find that privatization decreases both cement prices and the relative inflation rate. A switch from public ownership to private ownership decreases cement prices by $32 \%$. This finding is in sharp contrast to most of the earlier studies, which find that privatization results in an increase in prices (La Porta \& Lopez-deSilanes, 1999; Saal \& Parker, 2001). Hence, the link between privatization and allocative efficiency needs to be more closely examined. Changes in market structure resulting from privatization may be responsible for our results. We will explore this angle in Section 6(d).

\section{(c) Privatization and input choice}

How does a privatized firm change its production process to improve its productive efficiency? To answer this question, we analyze how privatization affects a firm's input choices. Our dependent variables in these regressions are labor, capital, capital labor ratio and investment (all in logs). All regressions, presented in Table 5, control for plant specific and period specific effects by adopting a firm fixed effect specification and including year dummies. We find that privatization has a negative and significant effect on labor (Regression 1) and this effect exists for both domestic and foreign buyer privatizations (Regression 2).

Although privatization has a positive and significant effect on capital (Regression 3), when we differentiate the privatization effect according to the type of buyer, we no longer find a significant effect for plants privatized to domestic buyers (Regression 4). Furthermore, the coefficient on the foreign dummy is positive, significant and quite large. This is an interesting result and indicates the importance of foreign buyers in increasing capital endowment of privatized plants. Capital labor ratio increases as a result of privatization for all plant types (Regressions 5 and 6). This must result from work force reductions for all privatized plants.

Table 5. Privatization and input choice method: fixed effects estimation (firm level)

\begin{tabular}{|c|c|c|c|c|c|c|c|c|}
\hline $\begin{array}{l}\text { Dependent } \\
\text { variable }\end{array}$ & $\begin{array}{c}\text { Labor } \\
(\log ) \\
(1)\end{array}$ & $\begin{array}{l}\text { Labor } \\
(\log ) \\
(2)\end{array}$ & $\begin{array}{l}\text { Capital } \\
\text { (log) } \\
\text { (3) }\end{array}$ & $\begin{array}{l}\text { Capital } \\
(\log ) \\
(4)\end{array}$ & $\begin{array}{c}\text { Capital/ } \\
\text { labor } \\
\text { ratio }(\log ) \\
\quad(5)\end{array}$ & $\begin{array}{l}\text { Capital/ } \\
\text { labor } \\
\text { ratio (log) } \\
\quad(6)\end{array}$ & $\begin{array}{l}\text { Investment } \\
\qquad(\log ) \\
(7)\end{array}$ & $\begin{array}{c}\text { Investment } \\
(\log ) \\
(8)\end{array}$ \\
\hline $\begin{array}{l}\text { Privatization } \\
\text { effect }\end{array}$ & $\begin{array}{c}-0.238^{* * *} \\
(-5.92)\end{array}$ & & $\begin{array}{c}0.385^{* * *} \\
(3.75)\end{array}$ & & $\begin{array}{c}0.418^{* * *} \\
(3.16)\end{array}$ & & $\begin{array}{l}0.786^{* *} \\
(2.08)\end{array}$ & \\
\hline Domestic & & $\begin{array}{c}-0.243^{* * *} \\
(-5.98)\end{array}$ & & $\begin{array}{l}0.126 \\
(1.11)\end{array}$ & & $\begin{array}{l}0.292^{* *} \\
(2.11)\end{array}$ & & $\begin{array}{l}0.597 \\
(1.59)\end{array}$ \\
\hline Foreign & & $\begin{array}{c}-0.190^{* * *} \\
(-2.79)\end{array}$ & & $\begin{array}{c}0.702^{* * *} \\
(5.82)\end{array}$ & & $\begin{array}{c}0.717^{* * *} \\
(4.15)\end{array}$ & & $\begin{array}{l}2.297^{* * *} \\
(3.70)\end{array}$ \\
\hline Year dummies & Yes & Yes & Yes & Yes & Yes & Yes & Yes & Yes \\
\hline$F$-statistic & 61.72 & 58.07 & 11.09 & 12.59 & 26.20 & 26.17 & 1.40 & 1.91 \\
\hline Overall $R^{2}$ & 0.741 & 0.742 & 0.228 & 0.248 & 0.510 & 0.530 & 0.090 & 0.16 \\
\hline $\begin{array}{l}\text { Test statistics for } \\
\text { the equality of } \\
\text { firm effects } \\
\text { ( } p \text {-value) }\end{array}$ & $\begin{array}{c}F=5.88 \\
(0.00)\end{array}$ & $\begin{array}{c}F=5.79 \\
(0.00)\end{array}$ & $\begin{array}{c}F=29.80 \\
(0.00)\end{array}$ & $\begin{array}{c}F=29.80 \\
(0.00)\end{array}$ & $\begin{array}{c}F=14.95 \\
(0.00)\end{array}$ & $\begin{array}{c}F=14.92 \\
\quad(0.00)\end{array}$ & $\begin{array}{c}F=4.56 \\
(0.00)\end{array}$ & $\begin{array}{c}F=4.36 \\
(0.00)\end{array}$ \\
\hline $\begin{array}{l}\text { Number of } \\
\text { observations }\end{array}$ & 266 & 266 & 243 & 243 & 165 & 165 & 260 & 260 \\
\hline
\end{tabular}

$t$-Statistics are in parentheses.

* Significant at $10 \%$.

** Significant at $5 \%$.

*** Significant at $1 \%$. 
As expected, our results on investment are similar to the ones obtained on capital. While the overall effect of privatization on investment is found to be positive and significant (Regressions 7), this effect disappears for plants privatized to domestic buyers and is enhanced for plants privatized to foreign buyers (Regression 8).

These results suggest that privatized plants reduce their work force significantly and plants privatized to foreign firms also increase their capital significantly. A switch from public to private ownership decreases the number of workers employed by $21 \%$ and increases the capital endowment by $47 \%$ though increases in capital are mostly due to privatizations to foreign buyers. Upon privatization, an average plant increases its investment by more than $100 \%$. The reduction in the number of employees as plants are privatized indicates the presence of excess and wasteful employment practices in the public sector. The drastic increase in investment and capital utilization accompanying the reduction in labor, however, also indicate a switch to a more capital intensive technology for plants privatized to foreign buyers. We should also note that the drastic increase in capital (assets) implies that the rate of return on assets, a variable often used in empirical studies of privatization, may not be an appropriate measure of performance in the short-run.

\section{(d) Privatization and market structure}

Privatization may affect productive and allocative efficiency in two ways. The first of these is the pure ownership effect; a public firm may experience a significant change in its objective function upon privatization as discussed in the theoretical literature section (ownership effect). Second, privatization may influence the market structure in which the firm operates and hence change the constraints faced by the firm (environment effect). In this section, we will examine the second effect more closely and determine whether we still observe an ownership effect on efficiency when we control for the effect of privatization on market structure.

Figures 1 and 2 present time series data for the region specific HHI for a western region (Marmara Region) and for an eastern region

\section{MARMARA REGION}

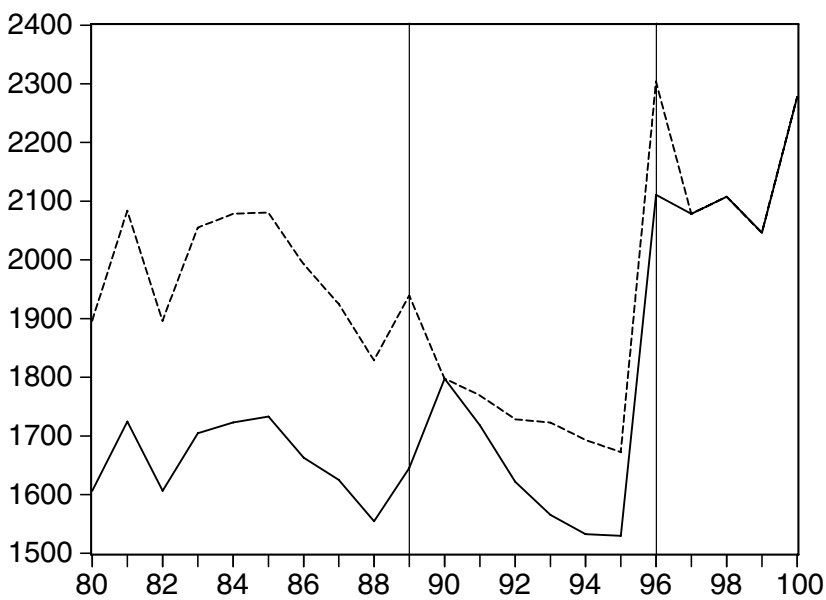

$$
----\mathrm{HHI}(2)-\mathrm{HHI}(1)
$$

Figure 1. The effects of privatization on market structure. Market concentration measured by Herfindahl index (HHI) $\left(H H I=\sum_{i=1}^{n} s_{i}^{2}\right.$ where $s_{i}$ is the market share (in \%) of plant $i$ and $n$ is the number of plants in the region. If two or more plants are owned by the same parent company, then market share of the parent company in the region is used for $s_{i}$. HHI(1) is the Herfindahl index including the publicly owned firms and HHI(2) excluding the publicly owned firms. In calculating HHI(1), share of output sold by publicly owned firms is considered as the share of a single firm-the public enterprise. In calculating $\mathrm{HHI}(2)$, only output sold by privately owned firms is considered. Vertical lines indicate the year of privatizations in the region.). A region in the West. 


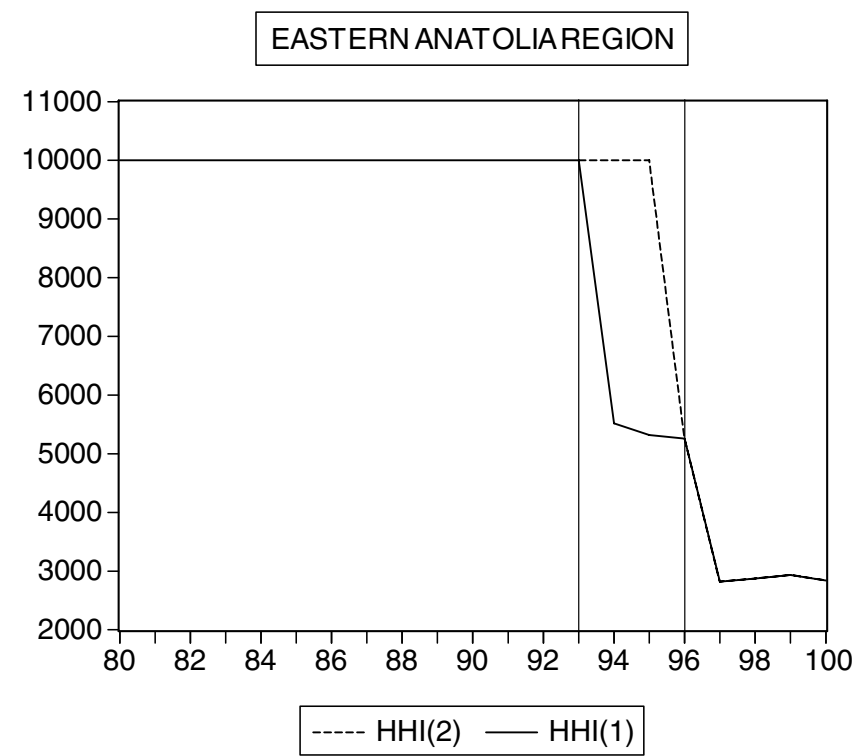

Figure 2. The effects of privatization on market structure. Market concentration measured by Herfindahl index (HHI) $\left(H H I=\sum_{i=1}^{n} s_{i}^{2}\right.$ where $s_{i}$ is the market share (in \%) of plant $i$ and $n$ is the number of plants in the region. If two or more plants are owned by the same parent company, then market share of the parent company in the region is used for $s_{i}$. $H H I(1)$ is the Herfindahl index including the publicly owned firms and HHI(2) excluding the publicly owned firms. In calculating HHI(1), share of output sold by publicly owned firms is considered as the share of a single firm-the public enterprise. In calculating $\mathrm{HHI}(2)$, only output sold by privately owned firms is considered. Vertical lines indicate the year of privatizations in the region.). A region in the East. Source: Constructed using plant level regional market share statistics from Turkish Cement Association.

(Eastern Anatolia Region), respectively. The time series spans the period from 1980 to 2000. The HHI is calculated by summing the squares of market shares of cement plants in each region. If two or more plants are owned by the same company, then the market share of the parent company in the region is used in the calculation. The higher the HHI is, the more concentrated the market will be. HHI(1) is the total HHI including the publicly owned plants and $\mathrm{HHI}(2)$ is the HHI excluding the publicly owned plants. In other words, in calculating $\mathrm{HHI}(1)$ we consider the share of output sold by publicly owned plants as the share of a single firm - the public enterprise. In calculating $\mathrm{HHI}(2)$, we only consider the output sold by privately owned plants (including privatized plants) and base our measure on how this private output is shared among the privately owned firms.

In Figures 1 and 2, the vertical lines on graphs indicate years in which privatizations took place in that region. The graphs suggest that $\mathrm{HHI}(1)$ increases in Marmara region and decreases in Eastern Anatolia Region. Furthermore, before privatization there seems to be a relatively competitive environment in the Marmara region, while Eastern Anatolia region did not have a single private plant. We should note that Marmara region is the most populous region, with the largest economy, in Turkey. Graphs for other regions are not presented but are available upon request. These graphs indicate that $\mathrm{HHI}(1)$ decreases in the Central and Southeast Anatolia regions after privatization, while there does not seem to be a significant change in $\mathrm{HHI}(1)$ in the Aegean and Black Sea regions.

These striking differences in the market structures of western and eastern regions before privatization might be partially responsible for the findings of earlier studies. Saygili and Taymaz (2001) find that public plants located in the west were not that different from private ones, while public plants located in the east were performing more poorly. Similarly, Tallant (1993) in his comparison of public plants with private ones points out that public plants 
located in the east were significantly worse performers than private ones. Hence, a competitive environment might be important in determining the firm's performance. Therefore, we should analyze the effect of privatization on market structure more closely.

In order to have a more in-depth analysis of how privatization affects market structure, we present OLS regression results using the $\mathrm{HHI}(1)$ data. Here our unit of analysis is a region of Turkey and our dependent variable is HHI(1) in that region. For example in the first regression of Table 6 , our dependent variable is $\mathrm{HHI}(1)$ in the Marmara region. Our explanatory variables, dummy 89 and dummy 96 , control for the structural shifts induced by the privatizations of 1989 and 1996 in the Marmara region. Dummy89 (dummy96) is equal to 1 in the post-1989 (1996) period and 0 otherwise. Since privatization years may differ across regions, the dummies used may differ across regressions. In general, our regression results seem to confirm our observations in the graphs. Privatization increases HHI in the Marmara region and decreases it in East and Southeast Anatolia regions. There is a mixed evidence for the Black Sea, Central Anatolia and Aegean regions.
Our first lesson here is that even for the same industry, different plants may face different competitive environments when transportation costs are important. Another lesson is that multiple industry studies of privatization (most empirical studies are of this kind) are likely to mask differences in market structure in which these firms operate. It is highly unlikely that privatization will have the same effect on market structure in every industry. To lump all these different effects into one privatization variable may be misleading.

We next examine how privatization affects productive and allocative efficiency when we control for the changes in market structure. Here our goal is to differentiate the ownership effect of privatization from its effects on the market structure and the competitive environment. Hence, we add two additional controls to our baseline regressions in Table 4: HHI(1) and a deregulation dummy (dummy86), which is equal to 1 post-1986 and is 0 otherwise. Deregulation dummy controls for the price deregulation which took place prior to the start of the privatization reforms. We present these results in Table 7.

The effects of privatization on productive efficiency remain virtually unchanged as shown in

Table 6. Privatization effects on market concentration method: ordinary least squares

\begin{tabular}{|c|c|c|c|c|c|c|}
\hline $\begin{array}{l}\text { Dependent } \\
\text { variable }\end{array}$ & $\begin{array}{c}\text { HHI } \\
\text { (Marmara) }\end{array}$ & $\begin{array}{c}\text { HHI } \\
\text { (Aegean) }\end{array}$ & $\begin{array}{c}\text { HHI } \\
\text { (Central Anatolia) }\end{array}$ & $\begin{array}{c}\text { HHI } \\
\text { (Black Sea) }\end{array}$ & $\begin{array}{c}\text { HHI } \\
\text { (East Anatolia) }\end{array}$ & $\begin{array}{c}\text { HHI (Southeast } \\
\text { Anatolia) }\end{array}$ \\
\hline Dummy89 & $\begin{array}{l}38.035 \\
(0.57)\end{array}$ & $\begin{array}{l}-90.666 \\
(-0.82)\end{array}$ & $\begin{array}{c}-1,176.36^{* * *} \\
(-13.15)\end{array}$ & & & \\
\hline Dummy92 & & $\begin{array}{c}-138.291 \\
(-1.21)\end{array}$ & $\begin{array}{c}432.191^{* * *} \\
(4.70)\end{array}$ & $\begin{array}{c}-2,260.206^{* * *} \\
(-11.69)\end{array}$ & & $\begin{array}{c}-2,503.593^{* * *} \\
(-3.99)\end{array}$ \\
\hline Dummy93 & & & & $\begin{array}{c}963.040^{* * *} \\
(4.47)\end{array}$ & $\begin{array}{c}-4,635.199^{* * *} \\
(-148.30)\end{array}$ & $\begin{array}{c}-398.664 \\
(-0.54)\end{array}$ \\
\hline Dummy95 & & & & & & $\begin{array}{c}-864.933 \\
(-1.43)\end{array}$ \\
\hline Dummy96 & $\begin{array}{c}430.765^{* * *} \\
(5.11)\end{array}$ & & & $\begin{array}{c}291.232^{*} \\
(2.05)\end{array}$ & $\begin{array}{c}-2,497.09^{* *} \\
(-66.55)\end{array}$ & \\
\hline Dummy97 & & & & & & $\begin{array}{c}-540.056 \\
(-0.73)\end{array}$ \\
\hline Dummy98 & & & & & & $\begin{array}{c}451.837 \\
(0.61)\end{array}$ \\
\hline$F$-statistic & 18.57 & 4.10 & 116.46 & 88.99 & $37,740.35$ & 34.44 \\
\hline$R^{2}$ & 0.674 & 0.313 & 0.9283 & 0.940 & 0.998 & 0.9199 \\
\hline $\begin{array}{l}\text { Number of } \\
\text { observations }\end{array}$ & 21 & 21 & 21 & 21 & 21 & 21 \\
\hline
\end{tabular}

$t$-Statistics are in parentheses.

* Significant at $10 \%$.

** Significant at 5\%.

*** Significant at $1 \%$. 
Table 7. Privatization effects controlling for market structure method: fixed effects estimation (firm level)

\begin{tabular}{|c|c|c|c|c|c|}
\hline \multirow[t]{2}{*}{ Dependent variable } & \multirow{2}{*}{$\begin{array}{l}\text { Productive efficiency } \\
\text { Labor } \\
\text { productivity } \\
(\log ) \\
\text { (1) }\end{array}$} & \multicolumn{3}{|c|}{ Allocative efficiency } & \multirow{2}{*}{$\begin{array}{c}\text { Capacity utilization } \\
\text { rate }(\%)\end{array}$} \\
\hline & & $\begin{array}{l}\text { Price } \\
(\log ) \\
(2)\end{array}$ & $\begin{array}{c}\text { Price } \\
(\log ) \\
(3)\end{array}$ & $\begin{array}{c}\text { Relative } \\
\text { inflation } \\
\text { (4) }\end{array}$ & \\
\hline Privatization effect & $\begin{array}{l}0.217^{* * *} \\
(4.90)\end{array}$ & $\begin{array}{l}-0.028 \\
(-1.17)\end{array}$ & $\begin{array}{l}-0.013 \\
(-0.51)\end{array}$ & $\begin{array}{l}-0.091^{* *} \\
(-2.06)\end{array}$ & $\begin{array}{l}0.0135 \\
(0.38)\end{array}$ \\
\hline $\mathrm{HHI}^{\mathrm{a}}$ (in 1000) & $\begin{array}{l}0.002 \\
(0.20)\end{array}$ & $\begin{array}{l}0.007 \\
(1.23)\end{array}$ & $\begin{array}{c}0.010^{* * * *} \\
(2.05)\end{array}$ & $\begin{array}{l}0.013 \\
(1.33)\end{array}$ & $\begin{array}{c}-0.038^{* * *} \\
(-4.84)\end{array}$ \\
\hline Deregulation effect (dummy86) & $\begin{array}{l}0.970^{* * *} \\
(8.97)\end{array}$ & & & $\begin{array}{c}-0.375^{* * *} \\
(-3.48)\end{array}$ & $\begin{array}{l}-0.130 \\
(-1.48)\end{array}$ \\
\hline Year dummies & Yes & Yes & Yes & Yes & Yes \\
\hline$F$-statistic & 97.42 & 43.37 & 43.69 & 39.64 & 4.48 \\
\hline Overall $R^{2}$ & 0.56 & 0.69 & 0.69 & 0.71 & 0.04 \\
\hline $\begin{array}{l}\text { Test statistic for the equality } \\
\text { of firm effects ( } p \text {-value) }\end{array}$ & $\begin{array}{c}F=28.85 \\
\quad(0.00)\end{array}$ & $\begin{array}{c}F=5.33 \\
(0.00)\end{array}$ & $\begin{array}{c}F=5.49 \\
(0.00)\end{array}$ & $\begin{array}{l}F=0.54 \\
\quad(0.00)\end{array}$ & $\begin{array}{c}F=14.16 \\
(0.00)\end{array}$ \\
\hline Number of observations & 266 & 194 & 193 & 329 & 266 \\
\hline
\end{tabular}

$t$-Statistics are in parentheses.

${ }^{a} \mathrm{HHI}(1)$ is used in all regressions except for Regression 3 where $\mathrm{HHI}(2)$ is used.

* Significant at $10 \%$.

** Significant at $5 \%$.

*** Significant at $1 \%$.

Regression 1. Privatization has still a positive and significant effect on labor productivity. $\mathrm{HHI}(1)$ is insignificant in this regression, whereas dummy 86 is positive and significant. ${ }^{9}$ However, we do observe some changes in the effects of privatization on allocative efficiency when we control for the market structure. In the price regression (Regression 2), the privatization effect, while still negative, is no longer significant and $\mathrm{HHI}(1)$ is positive though insignificant. Regression 3 is the same as Regression 2 where our dependent variable is again $\log$ price, but with one difference: $\mathrm{HHI}(2)$ is used as a regressor instead of $\mathrm{HHI}(1)$. The results are striking. Privatization is no longer significant but $\mathrm{HHI}(2)$ is positive and significant. This indicates the importance of market concentration in determining price. The more concentrated a market, is the higher the price will be. The privatization effect remains negative and significant in the relative inflation regression with $\mathrm{HHI}(1)$, but loses significance if $\mathrm{HHI}(2)$ is used instead. ${ }^{10}$ Since our panel is short for the price variable, we are not able to include a price deregulation dummy in Regressions 2 and 3.

These results highlight the importance of differentiating ownership and environment (market structure) effects of privatization. Ownership effect is sufficient to achieve gains in labor productivity but not in allocative efficiency. Clearly the objective function of the firm changes with changing ownership type. Profit motive appears sufficient to achieve gains in productive efficiency. However, controlling for changes in market structure, we do not find that the increase in productive efficiency due to private ownership will benefit consumers in the form of lower prices. Since cement industry is an oligopoly, market concentration is important in determining the competitive environment following privatization. According to standard models of oligopoly theory in homogeneous product industries such as cement (e.g., the Cournot model), prices are a decreasing function of marginal costs and an increasing function of market concentration. While privatization may lower the marginal costs of the firm due to increased labor productivity, it may very well increase market concentration if plants are sold to incumbent firms in the industry.

Advocates of privatization often hope that more productively efficient firms will reflect these efficiency gains in their prices and ignore the effects of privatization on market concentration and competitive environment. Our results show that it is crucial to analyze the market structure ensuing from privatization when privatization reforms are considered. There is often too much emphasis on revenue generation and productive efficiency aspects of privatization, with little attention paid to allocative efficiency. 
We admit that our geographical regions are crude measures of the appropriate market for each firm. It is possible that a plant in one region may sell in a neighboring region. Since our HHI measures are based on these geographical regions, one might question whether they are good measures of market concentration. To test the reliability of our HHI measures, we estimate the effects of $\mathrm{HHI}(1)$ on the capacity utilization rate. Here the hypothesis (which is based on standard models of oligopoly) is that in more concentrated markets (HHI high), firms have more market power to influence price by restricting output and reducing their capacity utilization rates. Our last regression in Table 7 presents this regression where the capacity utilization rate is the dependent variable. We find evidence confirming this hypothesis; HHI has a negative and significant effect on capacity utilization rate, while privatization has a positive but insignificant effect. This finding strengthens our confidence in our HHI as a measure for market concentration/ power in the industry.

\section{(e) Robustness checks}

\section{(i) Controlling for the business cycles}

Our yearly dummies may not accurately capture the effects of the business cycle on our firm performance measures. It would be interesting to see (1) how our measures move with the business cycle; and (2) whether the privatization effect is sensitive to controlling for the changes in the aggregate economy.
Hence, we present our results controlling for an industry production index which measures the production level in total manufacturing industries (Table 8). In Regressions 1, 3 and 4 , the dependent variables are our measures of productive efficiency (labor productivity) and allocative efficiency (price and the relative inflation rate).

The privatization effect remains positive and significant consistent with our earlier results on productive efficiency (Regression 1). Industry production index is positive and significant in the labor productivity regression, which is in line with our expectations. We expect a plant's output to be pro-cyclical. If the increase in a plant's labor utilization does not increase as much as its output, this would result in gains in productivity. The privatization effect remains negative and significant in the price and relative inflation rate regressions, which is also consistent with our earlier results on allocative efficiency (Regressions 3 and 4). Industry production index is negative and significant in the price and relative inflation regressions. This result is consistent with the findings of a recent paper on the Turkish economy, which shows that price and inflation are counter cyclical and argues that this constitutes a supply-driven model for the Turkish economy (Alper, 2004).

A second approach to controlling business cycle effects is comparing the performance of plants in our sample (sample A) with the average performance of a sample of private plants (sample B) in the industry. Plants in sample B have always been privately owned, whereas

Table 8. Privatization effects controlling for the business cycle method: fixed effects estimation (firm level)

\begin{tabular}{|c|c|c|c|c|}
\hline Dependent variable & $\begin{array}{l}\text { Labor productivity } \\
\text { (log) }\end{array}$ & $\begin{array}{l}\text { Productivity } \\
\text { difference }^{\mathrm{a}}\end{array}$ & $\begin{array}{l}\text { Price } \\
(\log )\end{array}$ & $\begin{array}{l}\text { Relative } \\
\text { inflation }\end{array}$ \\
\hline Privatization effect & $\begin{array}{l}0.215^{* * *} \\
(5.00)\end{array}$ & $\begin{array}{c}-24.295^{* * *} \\
(-6.03)\end{array}$ & $\begin{array}{l}-0.039^{*} \\
(-1.79)\end{array}$ & $\begin{array}{l}-0.085^{*} \\
(-1.91)\end{array}$ \\
\hline Industrial production index & $\begin{array}{l}0.021^{* * *} \\
(10.88)\end{array}$ & $\begin{array}{l}0.870^{* * *} \\
(5.55)\end{array}$ & $\begin{array}{l}-0.009^{* * *} \\
(-7.04)\end{array}$ & $\begin{array}{l}-0.003^{* *} \\
(-2.35)\end{array}$ \\
\hline Year dummies & Yes & Yes & Yes & Yes \\
\hline$F$-statistic & 103.94 & 28.23 & 46.71 & 41.76 \\
\hline$R^{2}$ & 0.563 & 0.566 & 0.696 & 0.701 \\
\hline $\begin{array}{l}\text { Test statistic for the equality } \\
\text { of firm effects ( } p \text {-value) }\end{array}$ & $\begin{array}{c}F=30.71 \\
(0.00)\end{array}$ & $\begin{array}{l}F=10.10 \\
\quad(0.00)\end{array}$ & $\begin{array}{c}F=5.27 \\
(0.00)\end{array}$ & $\begin{array}{c}F=0.56 \\
(0.94)\end{array}$ \\
\hline Number of observations & 266 & 247 & 194 & 329 \\
\hline
\end{tabular}

$t$-Statistics are in parentheses.

${ }^{a}$ Average sales productivity of privately owned cement plants minus sales productivity of privatized plant $i$.

* Significant at $10 \%$.

** Significant at 5\%.

*** Significant at $1 \%$. 
plants in sample A were publicly owned and privatized. The average labor productivity in sample A is higher than the average labor productivity in sample B in a given year. In fact, in sample A, labor productivity of a plant in a given year is lower than the average labor productivity in sample B in 234 out of 255 observations.

In Regression 2 of Table 8, the dependent variable is constructed by subtracting labor productivity of each plant in sample A from average labor productivity in sample $\mathrm{B}$ in a given year. We measure labor productivity as sales divided by labor rather than output divided by labor because we lack information on output for private plants. If plants in sample A improve their performance as a result of privatization, then the performance gap between them and plants in the private sector will decrease in the post-privatization period. If improvements in performance that we observe occur industry-wide due to some business cycle effect or some other aggregate change in the economy, then we do not expect any change in the performance gap. We find that productivity difference between privatized plant and the private sector average does decrease after privatization. We control for firm fixed effects and include year dummies to control for period effects in this regression.

\section{(ii) A random effects specification}

One criticism of the privatization process in the cement industry has been that better performing plants which were located in the west were privatized first, while poor performing plants in the east were privatized later (Saygili \& Taymaz, 2001). These authors also point out that big conglomerates (holding companies) had a tendency to acquire plants in specific regions and this caused the creation of regional monopolies in the cement industry after privatization. Plants in the eastern regions may also have been privatized last due to the relative political instability of the region throughout the 1980s and early 1990s.

In order to address the concern of unobserved heterogeneity at the regional level, we model the firm's effects as random and use firm-specific variables such as regional dummies as explanatory variables in our estimation. We construct regional dummies for the Marmara Region, Aegean Region, Black Sea Region, Central Anatolia Region, Southeast Anatolia and East Anatolia Region. The dummy that we leave out in this regression is the
Table 9. Privatization and efficiency method: random effects estimation (firm level)

\begin{tabular}{cccc}
\hline $\begin{array}{l}\text { Dependent } \\
\text { variable }\end{array}$ & $\begin{array}{c}\text { Labor } \\
\text { productivity } \\
(\log )\end{array}$ & $\begin{array}{c}\text { Price } \\
(\log )\end{array}$ & $\begin{array}{c}\text { Relative } \\
\text { inflation }\end{array}$ \\
\hline Privatization & $0.229^{* * *}$ & -0.031 & $-0.084^{* *}$ \\
effect & $(5.36)$ & $(-1.49)$ & $(-2.09)$ \\
Black Sea & -0.213 & -0.543 & $0.075^{*}$ \\
region dummy & $(-0.99)$ & $(-1.06)$ & $(1.89)$ \\
Agean region & 0.098 & -0.036 & 0.037 \\
dummy & $(0.26)$ & $(-0.62)$ & $(0.81)$ \\
Central Anatolia & -0.063 & -0.044 & $0.079^{* *}$ \\
region dummy & $(-0.30)$ & $(-0.90)$ & $(2.00)$ \\
East Anatolia & $-0.616^{* *}$ & -0.031 & $0.075^{*}$ \\
region dummy & $(-2.87)$ & $(-0.62)$ & $(1.82)$ \\
Southeast & $-0.380^{*}$ & $-0.098^{* *}$ & 0.054 \\
Anatolia & $(-1.85)$ & $(-2.04)$ & $(1.38)$ \\
region dummy & & & \\
Wald statistic & $1,649.76$ & 580.57 & 753.95 \\
Overall $R^{2}$ & 0.70 & 0.734 & 0.711 \\
Number of & 266 & 194 & 329 \\
observations & & & \\
\hline Statision & & &
\end{tabular}

$z$-Statistics are in parentheses.

* Significant at $10 \%$.

** Significant at $5 \%$.

Significant at $1 \%$.

dummy for the Marmara Region and, hence, the coefficients of region dummies are relative to those plants located in that region of Turkey. In all regressions presented in Table 9, we control for the privatization effect and time dummies in addition to region dummies.

In general, the signs and significance of the coefficients of the privatization effect are the same as those we found in the firm fixed effect regressions. One exception is the price regression (Regression 3 ), where the privatization effect though negative is no longer significant. This is consistent with our earlier results that privatization has no significant effect on price once we control for market structure using a HHI. Region dummies serve as proxies for the market structure within each region. The coefficients on East and Southeast Anatolia dummies are negative in the labor productivity regression, which supports the hypothesis that eastern plants are less productive compared to their western counterparts.

\section{(iii) Controlling for differences in privatization years}

Privatization years of firms differ in our sample, as shown in Table 1. One could argue that, since better performing plants located in the 
western region are privatized first, our privatization dummy is equal to 1 for these firms, while it is equal to 0 for the others for some of the years. Hence, the difference in performance between plants privatized earlier and plants privatized later might produce biased results. Hence, we group plants according to their privatization years and re-estimate our econometric equations separately for each group. For example, group 1 consists of plants that are privatized in 1989, group 2 is composed of plants privatized in 1992 and so on.

In general, our results for these sub-groups remain consistent with our earlier results. We find that privatization has a positive and significant effect on labor productivity of plants privatized in 1996 (and mostly located in the eastern regions) as well as for those plants privatized in 1989 (and located in the west) (not shown but available upon request). We lose significance in our results for the six plants privatized in 1993, 1997, and 1998. For the two plants privatized in 1997 and 1998, there may not be enough elapsed time in our data to exhibit improvement in performance. Interestingly, four of these six plants have been bought by the Rumeli Conglomerate and this group has been recently charged with criminal activity in their business practices, both by Turkish and US authorities. The Rumeli Cement Group's management and control was taken over by Savings Deposit and Insurance Fund of Turkey as of February 2004. This may highlight the importance of buyer competence in the privatization process in determining post-privatization efficiency.

\section{CONCLUSION}

According to Shirley and Walsh (2001), both theoretical and empirical literature are not conclusive about the merits of private ownership in monopolistic markets. We contribute to this literature with our analysis of privatization effects in the Turkish cement industry. This industry is an oligopoly as it consists of about eleven companies owning 39 plants in total and each plant has some monopoly power in its hinterland due to high transportation costs.

Using a longitudinal data set of cement plants, we find that the privatized plants improve their productive efficiency through work force reductions. Interestingly, while plants privatized to domestic buyers experience productivity gains as well as plants privatized to foreign companies, only the latter group increases its investment and capital intensity.

Our data set also allows us to explore the effects of privatization on allocative efficiency, which is an understudied topic in this field. Controlling for changes in market structure with a market concentration index, we do not find that the gains in productive efficiency due to private ownership will benefit consumers in the form of lower prices. While privatization does not reduce prices, market concentration tends to increase prices. Hence, it is crucial that the market structure ensuing from privatization is carefully analyzed as privatization reforms are considered. There is often too much em- phasis on productive efficiency and revenue generation aspects of privatization, with little attention paid to allocative efficiency. Interestingly enough, privatization of the Turkish Cement industry has led to an increase in market concentration in some regions, while it has increased competition in others. Governments that are concerned with allocative efficiency should exercise caution in sale of public enterprises to private firms that already have a significant market share in the industry.

Since we have pre- and post-privatization data for all the cement plants which were once public, we are able to avoid the endogeneity problem associated with sample selection which has been a problem for earlier research. Our results withstand various robustness checks addressing other possible problems associated with sample selection and unobserved heterogeneity.

\section{NOTES}

1. When the last publicly owned cement plant was privatized in 1998, Turkey was the seventh largest cement producer in the world. In consequent years, a decrease in production was caused by a decline in demand due to financial crisis and 1999 earthquake. Exports on the other hand increased by four times during 1990-2002 period and reached 9.9 million tons in 2002 .

2. A survey conducted by Djankov and Murrell (2002) examines the effects of privatization in transition econ- 
omies. They conclude that in most countries, privately owned firms perform better than state owned firms.

3. Afyon and Nigde Cimento were the only two plants that were sold through a combination of block sales and public share offerings. In case of Afyon Cimento, 51\% was sold via block sale in 1989 and the rest was sold in a public offering in 1991. All of Nigde Cimento was offered in a public offering in 1991 but only $12 \%$ was sold, the rest was sold via block sale to the OYAKSabanci group.

4. Long distance transport via water is less expensive and hence more common. This is the mode of transport preferred for exports.

5. Also privatized were the two cement grinding facilities. Since these were not full scale production plants, we exclude them from our estimations.

6. Two exceptions were Denizli and Lalapasa. These two public plants were established in 1987 and 1991, respectively, in order to meet the growing demand in the western regions.
7. Results on economic significance are calculated by the following formula: $\exp ($ coefficient -1$)$.

8. Consider the Cobb-Douglas production function, $Y=K^{\beta} L^{1-\beta}$, where $Y$ is output, $K$ is capital and $L$ is labor. Dividing both sides by $L$, we get $\frac{Y}{L}=\left(\frac{K}{L}\right)^{\beta}$. The left hand side of this equation is labor productivity and $K / L$ is capital labor ratio. We take the logarithm of both sides and estimate this equation in Regression 3 of Table 4. The coefficient on capital labor ratio is the estimate for $\beta$.

9. Since price deregulation precedes the start of privatization, we re-estimated the effects of privatization including three period dummies: the first dummy is set equal to one if the year is pre-deregulation, the second dummy is set equal to one if it is post-deregulation but pre-privatization, and the third dummy is set equal to one if it is a post-privatization period for the firm. The results of these estimations are consistent with our findings and are available upon request.

10. The latter regression is not shown but is available upon request.

\section{REFERENCES}

Alper, E. (2004). Nominal stylized facts of turkish business cycles. Bogazici University, Working Paper, \#10.

Anderson, J. H., Lee, Y., \& Murrell, P. (2000). Competition and privatization amidst weak institutions: Evidence from Mongolia. Economic Inquiry, 38(4), 527-549.

Angelucci, M., Estrin, S., Konings, J., \& Zolkiewski, Z. (2001). The effect of ownership and competitive pressure on firm performance in transition countries, Micro Evidence from Bulgaria, Romania and Poland. CEPR Discussion Paper: 2985.

Bhaskar, V., \& Khan, M. (1995). Privatization and employment: A study of the jute industry in Bangladesh. American Economic Review, 85, 267-273.

Boubakri, N., Cosset, J. C., \& Guedhami, O. (2005). Post privatization corporate governance: The role of ownership structure and investor protection. Journal of Financial Economics, 76(2), 369-399.

Dharwadkar, R. (2000). Privatization in emerging economies: An agency theory perspective. The Academy of Management Review, 25(3), 650-670.

Djankov, S., \& Murrell, P. (2002). Enterprise restructuring in transition: A quantitative survey. CEPR Discussion Papers: 3319.

Earle, J. S., \& Telegdy, A. (2002). Privatization methods and productivity effects in Romanian industrial enterprises. Journal of Comparative Economics, 30(4), 657-682.

Ehrlich, I., Gallais-Hamonno, G., Liu, Z., \& Lutter, R. (1994). Productivity growth and firm ownership:
An analytical and empirical investigation. Journal of Political Economy, 102(5), 1006-1038.

Ercan, M., \& Onis, Z. (2001). Turkish privatization: Institutions and dilemmas. Turkish Studies, 2(1), 109-134.

Ertuna, O. (1998). Constraints of privatization: The Turkish case. Bogazici University, Working Paper.

Frydman, R., Gray, C., Hessel, M., \& Rapaczynski, A. (1999). When does privatization work? The impact of private ownership on corporate performance in the transition economies. Quarterly Journal of Economics, 114(4), 1153-1191.

Karatas, C. (2001). Privatization in Turkey: Implementation, politics of privatization and performance results. Journal of International Development, 13, 93-121.

Kattuman, P., \& Domanski, R. (1997). Industrial concentration under shock therapy: Poland in the early transition years. University of Cambridge, ESRC Centre for Business Research Working Paper: WP76.

Kikeri, S., \& Nellis, J. (2004). An assessment of privatization. World Bank Research Observer, 19(1), $87-118$.

Klee, H. (2003). Summary of international cement industry structure and practice. Cement Sustainability Initiative, World Business Council for Sustainable Development, Geneva, Switzerland.

La Porta, R., \& Lopez-de-Silanes, F. (1999). The benefits of privatization: Evidence from Mexico. Quarterly Journal of Economics, 114(4), 1193-1242. 
Megginson, W., \& Netter, J. (2001). From state to market: A survey of empirical studies on privatization. Journal of Economic Literature, 39, 321-389.

Niskanen, W. (1975). Bureaucrats and politicians. Journal of Law and Economics, 18(3), 617-643.

Omran, M. (2004). The performance of state-owned enterprises and newly privatized firms: Does privatization really matter? World Development, 32(6), 1019-1041.

Orta Anadolu Ihracatcilar Birligi, Cimento Sektoru Raporu (2003). Central Anatolian Board of Export, Cement Industry Report.

Ozmucur, S. (1998). Privatization and the labor market in Turkey. In Tuncer Bulutay (Ed.), Main characteristics and trend of the Turkish labour market (pp. 171-209). Ankara: State Institute of Statistics.

Ramamurti, R. (2000). A multilevel model of privatization in emerging economies. The Academy of Management Review, 25(3), 525-551.

Saal, D., \& Parker, D. (2001). Productivity and price performance in the privatized water and sewerage companies of England and Wales. Journal of Regulatory Economics, 20(1), 61-90.

Saygili, S., \& Taymaz, E. (2001). Privatization, ownership and technical efficiency: A study of the Turkish Cement Industry. Annals of Public and Cooperative Economics, 74(4), 581-605.

Shapiro, C., \& Willig, R. (1990). Economic rationales for the scope of privatization. In B. N. Suleiman, \& J.
Waterbury (Eds.), The political economy of public sector reform and privatization (pp. 55-87). London: Westview Press.

Shirley, M., \& Walsh, P. (2001). Public versus private ownership: Current state of debate. The World Bank, Policy Research Working Paper Series, No. 2420.

Shleifer, A., \& Vishny, R. (1994). Politicians and firms. Quarterly Journal of Economics, 109, 995-1025.

Shleifer, A., \& Vishny, R. (1997). A survey of corporate governance. Journal of Finance, 52(2), 737-783.

Tallant, D. (1993). Relative efficiency of public and private sector ownership and privatization of the Turkish Cement Industry. Review of Social, Economic and Administrative Studies, 7(1-2), 73-103.

Vickers, J., \& Yarrow, G. (1988). Privatization: An economic analysis. MIT Press Series on the Regulation of Economic Activity (Vol. 18). Cambridge, MA: MIT Press.

Villalonga, B. (2000). Privatization and efficiency: Differentiating ownership effects from political, organizational, and dynamic effects. Journal of Economic Behavior \& Organization, 42, 43-74.

Wallsten, S. J. (2001). An econometric analysis of telecom competition, privatization, and regulation in Africa and Latin America. Journal of Industrial Economics, 49, 1-19.

Warzynski, F. (2003). Managerial change, competition and privatization in Ukraine. Journal of Comparative Economics, 31, 297-314. 